\title{
PENGARUH BRAND IMAGE DAN KUALITAS PRODUK TERHADAP KEPUTUSAN BERKUNJUNG KE RESTO FORESTHREE
}

\author{
Annisa Rizkia Arif, I Made Adhi Gunadi \\ Annisarizkiaarif@gmail.com \\ Fakultas Pariwisata Universitas Pancasila
}

\begin{abstract}
This research at Foresthree restaurant is aimed to determine the influence of brand image and product quality on visiting decisions. There are several factors influencing a visiting decision, therefore this research aim to know the influence of brand image and product quality. The research method used is a quantitative method, where the variables to be tested are corporate image, product image, user image variables according to Aaker and Biel (1993) theory and product quality according to West, Wood, and Harger (2006). Data is collected by interviews and questionnaires conducted in July 2018 with purposive sampling technique. Data is presented in quantitative descriptive manner. The findings of this research indicate that the corporate image and product image variables have a significant effect on the decision to visit Foresthree restaurant, while the user image and product quality have no significant effect on the decision to visit Foresthree restaurant.
\end{abstract}

Keywords: Brand Image, Product Quality, Decision to Visit.

\section{PENDAHULUAN}

Atraksi wisata merupakan salah satu komponen dalam pariwisata dan salah satu faktor penarik pergerakan wisatawan menuju daerah tujuan wisata. Ciri khas atraksi wisata pada sebuah negara atau daerah merupakan modal dasar untuk mengembangkan pariwisata. Biasanya, atraksi dapat ditemui sebagai hal yang sudah dimiliki turun temurun/melekat, khas, unik, natural, dan asli. Atraksi wisata juga dapat dikatakan sebagai faktor penarik wisatawan, yang paling utama dalam menghadirkan banyak wisatawan sehingga atraksi wisata memiliki keunikan dan keunggulan yang berbeda dari wilayah lainnya.

Pariwisata menurut daya tariknya

Volume 6 No.2 Desember2018, ISSN: 2339-1987 menurut Fandeli (1995) dapat dibedakan menjadi tiga bagian, yaitu daya tarik alam, daya tarik budaya atau heritage, dan daya tarik minat khusus. Daya tarik minat khusus seperti wisata kuliner merupakan suatu perjalanan yang didalamnya meliputi kegiatan mengkonsumsi makanan lokal dari suatu daerah, perjalanan dengan tujuan utamanya adalah menikmati makanan dan minuman dan atau mengunjungi suatu kegiatan kuliner, seperti sekolah memasak, mengunjungi pusat industri makanan dan minuman serta untuk mendapatkan pengalaman yang berbeda ketika mengonsumsi makanan dan minuman.

Bogor merupakan salah satu wilayah yang di provinsi Jawa Barat, Indonesia yang berkembang menjadi destinasi wisata bagi wisatawan lokal maupun mancanegara. Sebagian orang mengenal Bogor berkat julukan "Kota 
Seribu Angkot". Padahal disamping itu, Bogor memiliki pesona wisata baik alam, religi, maupun kuliner yang sangat menarik untuk ditelisik dan dikunjungi. Bogor mempunyai beberapa kuliner serta tempat wisata populer, bahkan menginspirasi daerah-daerah lain untuk meningkatkan potensi kepariwisataan. Sektor perdagangan, atraksi wisata, hotel, dan restoran selalu menjadi sektor andalan di Bogor sehingga tidak salah untuk dikatakan bahwa perekonomian Bogor bergantung pada pengembangan pariwisata yang berkelanjutan. Berkembangnya wisata kuliner serta persaingan yang semakin meningkat, restoran perlu menjaga brand image (citra merek) serta kualitas produk yang dimiliki untuk meningkatkan daya tarik wisatawan lokal maupun mancanegara. Ketatnya persaingan bisnis dalam bidang kuliner seperti resto, membawa konsekuensi pengusaha retail dibidang kuliner dengan mengupayakan berbagai macam strategi untuk menarik konsumen. Dalam penelitian terdahulu oleh Pajrin (2016), salah satu komponen dalam keputusan pembelian adalah merek, dimana merek sangat berpengaruh bagi konsumen.

\section{Brand Image merupakan} serangkaian asosiasi yang ada dalam benak konsumen terhadap suatu brand, biasanya terorganisasi menjadi suatu makna. Hubungan terhadap suatu brand akan semakin kuat jika didasarkan pada pengalaman dan mendapat banyak informasi (Aaker 1991). Bila suatu merek telah memiliki citra positif dimata konsumen, maka konsumen tersebut lebih memungkinkan untuk melakukan keputusan pembelian. Brand yang lebih baik juga menjadi dasar untuk membangun citra perusahaan yang positif. Selain itu merek dapat meningkatkan efisiensi pembeli, dengan adanya nama/merek maka akan memudahkan pembeli menemukan produk yang dicari/diminati. Hal ini tentunya lebih efisien dan efektif. Kualitas merupakan totalitas fitur dan karakteristik produk atau jasa yang bergantung pada kemampuannya untuk memuaskan kebutuhan konsumen. Jika kualitas dari produk yang ditawarkan telah baik serta dipercaya oleh konsumen, maka produk senantiasa akan tertanam dibenak konsumen, karena itu konsumen bersedia membayar sejumlah uang untuk membeli produk yang ditawarkan. Persepsi konsumen terhadap kualitas produk akan membentuk preferensi dan sikap yang pada gilirannya akan mempengaruhi keputusan untuk membeli atau tidak. Kepercayaan pada sebuah merk memegang peranan penting dalam keputusan berkunjung. Dalam hal ini, konsumen percaya bahwa merk mempunyai citra perusahaan, citra produk, dan citra pemakai serta kualitas produk yang positif merupakan suatu jaminan untuk suatu produk.

Foresthree, merupakan salah satu resto yang berada di kota Bogor. Saat ini resto sudah menjamur diberbagai kota besar. Puluhan bahkan ratusan resto menyengat seperti wabah ke penjuru kota di Indonesia. Persaingan bisnis restoran mengharuskan pihak manajemen resto untuk selalu berorientasi kepada kepentingan konsumen dan untuk meraih pangsa pasar yang lebih besar. Resto Foresthree memiliki keunikan tersendiri yaitu memiliki ciri khas terdapat pohon buatan yang cukup besar ditengah- tengah ruangan, dinding-dinding yang dipenuhi tanaman asli yang menghijaukan serta dekat pintu masuk terdapat properti mobil tua yang merupakan tempat untuk berfoto. Selain itu resto ini memiliki 3 jenis interior yaitu meja dan kursi 
yang sesuaikan untuk keluarga, lalu cozy zone (untuk anak muda), serta romantic atau formal zone. Foresthree terus mencoba menyediakan produk yang berkualitas dan pelayanan yang maksimal. Produk yang ada di Foresthree merupakan produk makanan dan minuman yang sehat dan menggunakan bahan utama yang segar dari petani Bogor. Selain dikota Bogor, Foresthree memiliki cabang di Jakarta Selatan yaitu di Panglima Polim. Konsepnya tetap sama hanya saja bedanya di cabang ini bagi konsumen yang meiliki kartu mahasiswa akan mendapatkan potongan harga $15 \%$.

Menurut Kotler (2005) dalam meningkatkan persaingan masing-masing perusahaan harus dapat memenangkan persaingan tersebut dengan menampilkan produk yang terbaik serta dapat memenuhi selera konsumen yang selalu berkembang dan berubah-ubah. Saat ini Foresthree menjadi salah satu resto yang berkembang di kota Bogor khususnya kalangan anak muda. Berikut adalah grafik jumlah konsumen yang datang pada bulan Juni 2018:

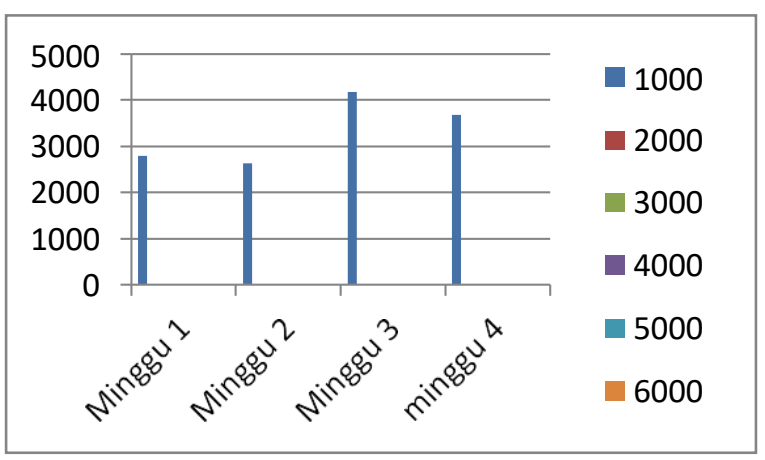

Gambar 1. Data jumlah konsumen Foresthree bulan Juni 2018 Sumber: Dokumen Pribadi

Dilihat dari banyaknya jumlah konsumen bulan Juni 2018 yang mencapai 14.287 merupakan pencapaian yang tinggi. Tetapi jumlah konsumen mengalami penurunan pada tanggal 26 Juni 2018 yaitu kurang dari 200 konsumen, namun kembali meningkat lagi dihari selanjutnya dan menurun kembali dihari berikutnya. Hal ini diduga yang mempengaruhi tingkat persaingan bisnis adalah brand image dan kualitas produk. Gaya hidup masyarakat yang selalu berubahubah dari masa ke masa memungkinkan keberadaan brand image dan kualitas produk menjadi faktor dalam memilih keputusan berkunjung.

Dari uraian diatas yang menjelaskan tentang brand image dan kualitas produk maka tujuan penelitian ini untuk menganalisa pengaruh Brand Image dan Kualitas Produk terhadap keputusan berkunjung ke resto Foresthree, baik secara parsial maupun simultan. (lihat gambar 2 . Kerangka Pemikiran).

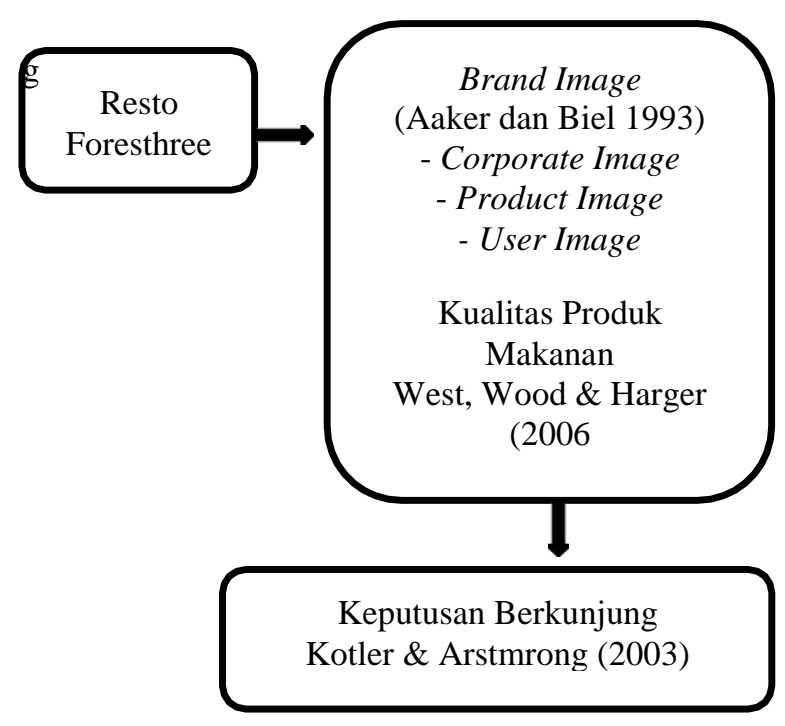

Gambar 2. Kerangka Pemikiran

\section{HIPOTESIS}

Dari kerangka pemikiran tersebut, hipotesis yang dapat dirumuskan adalah sebagai berikut:

1. Corporate Image (X1)

$\mathrm{H} 1 \mathrm{a}$ : Corporate Image berpengaruh 
signifikan terhadap keputusan berkunjung ke resto Foresthree.

H1o: Corporate Image tidak berpengaruh signifikan terhadap keputusan berkunjung ke resto Foresthree.

\section{Product Image (X2)}

H2a: Product image berpengaruh signifikan terhadap keputusan berkunjung ke resto Foresthree.

H2o: Product image tidak berpengaruh signifikan terhadap keputusan berkunjung ke resto Foresthree.

\section{User Image (X3)}

H3a: User image berpengaruh signifikan terhadap keputusan berkunjung ke resto Foresthree.

H3o: User image tidak berpengaruh signifikan terhadap keputusan berkunjung ke resto Foresthree.

\section{Kualitas Produk (X4)}

H4a: Kualitas produk berpengaruh signifikan terhadap keputusan berkunjung ke resto Foresthree. H4o: Kualitas produk tidak berpengaruh signifikan terhadap keputusan berkunjung ke resto Foresthree.

\section{METODE}

Sasaran yang menjadi sumber penelitian ini adalah konsumen resto Foresthree yang membeli dan mengkonsumsi produk resto Foresthree. Populasi diambil dari konsumen bulan Juni 2018 sejumlah 14.287 (lihat gambar.1) untuk mendapatkan sampel. Maka jumlah sampel dalam penelitian ini ditentukan dengan menggunakan rumus Slovin adalah 100 responden.

Penelitian ini menggunakan pendekatan kuantitatif, yang merupakan data yang dipaparkan dalam bentuk angka. Data yang digunakan biasanya data statistik. Data tersebut berupa jumlah konsumen.

$$
\text { Pada penelitian ini metode }
$$
pengumpulan data adalah dengan observasi, wawancara, dan kuesioner yang disebarkan kepada responden. Pengukuran variabel dilakukan dengan menggunakan skala likert (1-5). Skala likert paling sering digunakan untuk mengukur sikap, pendapat, persepsi responden seseorang/kelompok orang dengan fenomena sosial.

Untuk menyusun kuesioner, perlu dilakukan operasional variabel yaitu pernyataan yang sangat jelas sehingga tidak menimbulkan kesalah pahaman penafsiran karena dapat diobservasi dan dibuktikan perilakunya (Purwanto, 2007). Operasional variabel dapat dilihat pada tabel 1 .

Tabel 1. Definisi Operasional Variabel

\begin{tabular}{|c|c|c|}
\hline Variabel & Sub Variabel & Indikator \\
\hline $\begin{array}{l}\text { Brand Image } \\
\text { (Aaker \& } \\
\text { Biel 1993) }\end{array}$ & $\begin{array}{l}\text { Corporate } \\
\text { Image } \\
\text { Product } \\
\text { Image User } \\
\text { Image }\end{array}$ & $\begin{array}{l}\text { Corporate } \\
\text { Image: } \\
\text { popularitas, } \\
\text { kredibilitas, } \\
\text { jaringan } \\
\text { perusahaan. } \\
\text { Product Image: } \\
\text { atribut produk, } \\
\text { manfaat } \\
\text { produk, serta } \\
\text { jaminan. }\end{array}$ \\
\hline & & $\begin{array}{l}\text { User Image: } \\
\text { pemakai, } \\
\text { status sosial. }\end{array}$ \\
\hline $\begin{array}{l}\text { Kualitas } \\
\text { Produk } \\
\text { (West, Wood } \\
\text { dan Harger } \\
\text { 2006) }\end{array}$ & $\begin{array}{l}\text { Warna, } \\
\text { penampilan, } \\
\text { porsi, bentuk, } \\
\text { temperatur, } \\
\text { tekstur, } \\
\text { aroma, } \\
\text { tingkat } \\
\text { kematangan, }\end{array}$ & $\begin{array}{l}\text { Warna: warna } \\
\text { yang menarik } \\
\text { dari } \\
\text { makanan. } \\
\text { Penampilan: } \\
\text { tampilan } \\
\text { makanan dan } \\
\text { minuman yang }\end{array}$ \\
\hline
\end{tabular}




\begin{tabular}{|c|c|c|}
\hline & rasa. & $\begin{array}{l}\text { menarik } \\
\text { perhatian } \\
\text { konsumen. } \\
\text { Porsi: memiliki } \\
\text { porsi yang } \\
\text { sesuai.. } \\
\text { Bentuk: } \\
\text { pemotongan } \\
\text { bahan makanan. } \\
\text { Temperatur: } \\
\text { kesesuaian } \\
\text { temperatur } \\
\text { makanan. } \\
\text { Tekstur: } \\
\text { kesesuaian } \\
\text { tekstur makanan, } \\
\text { variasi tekstur. } \\
\text { Aroma: aroma } \\
\text { yang dapat } \\
\text { menggugah } \\
\text { selera. } \\
\text { Tingkat } \\
\text { kematangan: } \\
\text { kesesuaian } \\
\text { tingkat } \\
\text { kematangan } \\
\text { dengan jenis } \\
\text { makanannya. } \\
\text { Rasa: cita rasa } \\
\text { makanan yang } \\
\text { sesuai dengan } \\
\text { harapan. }\end{array}$ \\
\hline $\begin{array}{l}\text { Keputusan } \\
\text { Berkunjung } \\
\text { (Kotler \& } \\
\text { Armstrong } \\
\text { 2003). }\end{array}$ & $\begin{array}{l}\text { Melakuka } \\
\mathrm{n} \\
\text { pembelian } \\
\text { produk. } \\
\text { Rekomendasi }\end{array}$ & $\begin{array}{l}\text { Mereferensikan } \\
\text { kepada calon } \\
\text { pengunjung lain. }\end{array}$ \\
\hline
\end{tabular}

Teknik analisis data yang digunakan dalam penelitian ini adalah analisis regresi berganda yang merupakan suatu metode analisa yang digunakan untuk menentukan

Volume 6 No.2 Desember2018, ISSN: 2339-1987 ketepatan prediksi dari pengaruh yang terjadi antara variabel independen $(\mathrm{X})$ terhadap variabel dependen (Y).

Formula untuk regresi berganda sebagai berikut :

$$
\mathrm{Y}=\mathbf{a}+\mathrm{b} 1 \mathrm{X} 1+\mathrm{b} 2 \mathrm{X} 2+\mathrm{e}
$$

Keterangan :

Y : Keputusan berkunjung (variabel dependen) X1 : Variabel brand image (variabel independen)

X2 : Variabel kualitas produk (variabel independen) a : Konstanta

b1 : Koefisien regresi variabel brand image b2 : Koefisien regresi variabel kualitas produk $e:$ error

Uji Parsial (Uji T) yaitu suatu uji untuk mengetahui signifikasi dari pengaruh variable independen terhadap variabel dependen secara individual dan menganggap dependen yang lain konstan.

Uji Simultan (Uji F) dikenal dengan Uji serentak atau uji Model/Uji Anova, yaitu uji untuk melihat bagaimanakah pengaruh semua variabel bebasnya secara bersamasama terhadap variabel terikatnya.

Menurut Ghozali (2013) koefisien determinasi pada intinya mengukur seberapa jauh kemampuan model dalam menerangkan variasi variabel dependen. Nilai koefisien determinasi adalah antara nol dan satu.

Validitas data merupakan ketepatan antar data yang terjadi pada obyek penelitian dengan data yang dilaporkan oleh peneliti. Uji validitas data yang dilakukan pada setiap pertanyaan menghasilkan p- value <alpha 0,05 yang berarti seluruh pertanyaan dinyatakan valid. Sedangkan uji reliabilitas merupakan alat ukur untuk mengukur suatu 
kuesioner yang merupakan indicator dari variable. Suatu variabel dikatakan reliabel jika memberikan nilai Cronbach's Alpha >0,60. 


\section{HASIL \& PEMBAHASAN}

\section{Hasil Regresi Berganda dan Uji Data}

Dari data yang sudah dikumpulkan berupa kuesioner kemudian diolah menggunakan SPSS 15.0. Proses pengolahan data menggunakan hasil dari kuesioner untuk dapat dihitung lebih lanjut menggunakan uji regresi berganda.

\section{Uji Parsial (T)}

Uji $\mathrm{T}$ digunakan untuk mengetahui apakah masing-masing variabel bebas secara parsial mempunyai pengaruh yang signifikan terhadap variabel terikat. Dapat juga dikatakan jika $\mathrm{t}$ hitung $>\mathrm{t}$ tabel atau $-\mathrm{t}$ hitung $<\mathrm{t}$ tabel maka hasilnya signifikan dan berarti Ho ditolak dan Ha diterima. Sedangkan jika t hitung $<\mathrm{t}$ tabel atau $-\mathrm{t}$ hitung > t tabel maka hasilnya tidak signifikan dan berarti Ho. Berikut adalah tabel hasil uji $\mathrm{T}$ :

Tabel 2. Hasil uji T

\begin{tabular}{|c|c|c|c|c|c|}
\hline \multirow[t]{2}{*}{ Model } & \multicolumn{2}{|c|}{$\begin{array}{l}\text { Unstandardize } \\
\text { d Coefficients }\end{array}$} & \multirow{2}{*}{$\begin{array}{c}\begin{array}{c}\text { Standar } \\
\text { dized } \\
\text { Coefficie } \\
\text { nts }\end{array} \\
\text { Beta }\end{array}$} & \multirow[b]{2}{*}{$B$} & \multirow{2}{*}{$\begin{array}{c}\text { Sig. } \\
\text { Std. } \\
\text { Error }\end{array}$} \\
\hline & B & $\begin{array}{l}\text { Std. } \\
\text { Error }\end{array}$ & & & \\
\hline \multirow{5}{*}{$\begin{array}{ll}1 & \text { nstant) } \\
& \text { totalcor } \\
\text { porate } \\
\text { totalpro } \\
\text { duct } \\
\text { totaluse } \\
r \\
\text { totalkual } \\
\text { itas }\end{array}$} & 6.551 & 1.246 & & 5.259 & .000 \\
\hline & .219 & .082 & .269 & 2.673 & .009 \\
\hline & -.153 & .069 & -.215 & $2.233^{-}$ & .028 \\
\hline & .028 & .090 & .031 & .316 & .752 \\
\hline & .030 & .022 & .131 & 1.357 & .178 \\
\hline
\end{tabular}

a Dependent Variable: total keputusan Sumber: Peneliti (2018)

\section{Hipotesis 1}

H1a: Corporate Image berpengaruh signifikan terhadap keputusan berkunjung ke resto Foresthree. H1o: Corporate Image tidak berpengaruh signifikan terhadap keputusan berkunjung ke resto Foresthree.

Berdasarkan hasil pengolahan data melalui pengujian hipotesa diatas ditemukan hasil bahwa variabel corporate image (X1) memiliki nilai koefisien regresi sebesar 0.009 lebih kecil dari tingkat signifikasi $(<0.05)$ maka Ha diterima dan Ho ditolak. Dengan demikian dapat dinyatakan bahwa variabel corporate image (X1) berpengaruh signifikan terhadap keputusan berkunjung ke resto Foresthree.

\section{Hipotesis 2}

H2a: Product image berpengaruh signifikan terhadap keputusan berkunjung ke resto Foresthree.

H2o: Product image tidak berpengaruh signifikan terhadap keputusan berkunjung ke resto Foresthree.

Berdasarkan hasil pengolahan data melalui pengujian hipotesa diatas ditemukan hasil bahwa variabel product image (X2) memiliki nilai koefisien regresi sebesar 0.028 lebih kecil dari tingkat signifikasi $(<0.05)$ maka Ha diterima dan Ho ditolak. Dengan demikian dapat dinyatakan bahwa variabel product image berpengaruh signifikan terhadap keputusan berkunjung ke resto Foresthree.

\section{Hipotesis 3}

H3a: User image berpengaruh signifikan terhadap keputusan berkunjung ke resto Foresthree.

H3o: User image tidak berpengaruh signifikan terhadap keputusan berkunjung ke resto Foresthree.

Berdasarkan hasil pengolahan data melalui pengujian hipotesis diatas ditemukan hasil bahwa variabel user image (X3) memiliki nilai koefisien regresi sebesar 0.752 lebih besar dari tingkat signifikasi $(<0.05)$ maka Ho diterima dan Ha ditolak. Dengan demikian dapat dinyatakan bahwa variabel 
user image tidak berpengaruh signifikan terhadap keputusan berkunjung ke resto Foresthree.

\section{Hipotesis 4}

H4a: Kualitas produk berpengaruh signifikan terhadap keputusan berkunjung ke resto Foresthree.

H4o: Kualitas produk tidak berpengaruh signifikan terhadap keputusan berkunjung ke resto Foresthree.

Berdasarkan hasil pengolahan data melalui pengujian hipotesa diatas ditemukan hasil bahwa variabel kualitas produk (X4) memiliki nilai koefisien regresi sebesar 0.178 lebih besar dari tingkat signifikasi $(<0.05)$ maka Ho diterima dan Ha ditolak. Dengan demikian dapat dinyatakan bahwa variabel kualitas produk tidak berpengaruh signifikan terhadap keputusan berkunjung ke resto Foresthree.

\section{Hasil Uji Secara Simultan (F)}

Pengujian F dilakukan untuk mengetahui apakah hasil dari analisis regresi yang dilakukan terhadap variabel bebas (X) secara bersama- sama berpengaruh signifikan dengan variabel terikat (Y). Uji F dapat dilakukan dengan membandingkan $\mathrm{F}$ hitung > dari $\mathrm{F}$ tabel atau signifikan kurang dari 0,05 maka Ho ditolak dan sebaliknya, jika $\mathrm{F}$ hitung < dari $\mathrm{F}$ tabel atau signifikan lebih dari 0,05 maka Ho diterima. Penelitian dengan analisa regresi ini digunakan untuk menghitung besarnya pengaruh antara variabel bebas brand image yaitu corporate image (X1), product image (X2) serta user image (X3) dan kualitas produk (X4) terhadap variabel terikat yaitu keputusan berkunjung (Y).

Berikut adalah tabel hasil uji F:
Tabel 3. Hasil Uji F Brand Image

\begin{tabular}{|c|c|c|c|c|c|c|}
\hline $\begin{array}{l}\text { Mo } \\
\text { del }\end{array}$ & & $\begin{array}{l}\text { Sum of } \\
\text { Square } \\
\text { s }\end{array}$ & $d f$ & $\begin{array}{l}\text { Mean } \\
\text { Square }\end{array}$ & $\mathrm{F}$ & Sig. \\
\hline 1 & $\begin{array}{l}\text { Regressi } \\
\text { on } \\
\text { Residual } \\
\text { Total }\end{array}$ & $\begin{array}{r}12.596 \\
95.594 \\
108.19 \\
0\end{array}$ & $\begin{array}{r}3 \\
96 \\
99\end{array}$ & $\begin{array}{r}4.199 \\
.996\end{array}$ & 4.216 & $.008(a)$ \\
\hline
\end{tabular}

(b)

a Predictors: (Constant), totaluser, totalproduct, totalcorporate

b Dependent Variable: totalkeputusan

Tabel 4. Hasil Uji F Kualitas produk

\begin{tabular}{|ll|r|r|r|r|r|}
\hline \multicolumn{2}{|l|}{$\begin{array}{l}\text { Mod } \\
\text { el }\end{array}$} & $\begin{array}{r}\text { Sum of } \\
\text { Square } \\
\text { s }\end{array}$ & df & $\begin{array}{c}\text { Mean } \\
\text { Square }\end{array}$ & F & Sig. \\
\hline 1 & $\begin{array}{l}\text { Regressi } \\
\text { on }\end{array}$ & $\begin{array}{r}2.687 \\
105.50\end{array}$ & 1 & 2.687 & 2.496 & $.117(\mathrm{a})$ \\
& Residual & 98 & 1.077 & & \\
& Total & $\begin{array}{r}108.19 \\
0\end{array}$ & 99 & & & \\
& & & & & \\
\hline
\end{tabular}

ANOVA(b)

a Predictors: (Constant), totalkualitas

b Dependent Variable: totalkeputusan

Sumber: Peneliti (2018)

Berdasarkan tabel diatas menunjukan hasil pengujian uji $F$ untuk mengetahui pengaruh brand image dan kualitas produk secara bersama-sama. Variabel brand image memiliki estimasi $\mathrm{F}$ sebesar 4.216 dengan nilai signifikan sebesar 0.008 lebih kecil dari 0,05 maka dapat dinyatakan Ha diterima dan Ho ditolak. Hal ini berarti bahwa variabel brand image dalam penelitian ini berpengaruh secara simultan terhadap keputusan berkunjung ke resto Foresthree.

Hasil penelitian ini sejalan dengan penelitian sebelumnya oleh Pajrin (2016).

Variabel kualitas produk memiliki estimasi F sebesar 2.496 dengan nilai signifikan sebesar 0,117 lebih besar dari 0,05, maka dapat dinyatakan Ho diterima dan $\mathrm{Ha}$ 
ditolak. Hal ini berarti bahwa variabel kualitas produk dalam penelitian ini tidak berpengaruh secara simultan terhadap keputusan berkunjung ke resto Foresthree. Dalam hal tersebut, brand image memberikan pengaruh yang berkontribusi positif terhadap keputusan berkunjung ke resto Foresthree, sedangkan kualitas produk hanya menjadi faktor pelengkap.

\section{Hasil Uji Koefisien Determinan $\left(\mathbf{R}^{2}\right)$}

Koefisien determinan (Nilai R square) berguna untuk mengukur kemampuan model dalam menerangkan variabel dependen. Nilai $\mathrm{R}^{2}$ berkisar antara 0-1. Semakin mendekati 1 maka semakin besar variabel independen kontribusi variabel bebas brand image (X1) dan kualitas produk (X2) serta variabel terikat keputusan berkunjung (Y) digunakan nilai $\mathrm{R}^{2}$. Hasil perhitungan koefisien determinan disajikan pada tabel berikut:

Tabel 5. Hasil Uji Koefisien Determinan $\left(\mathrm{R}^{2}\right)$ Brand Image

Model Summary

\begin{tabular}{|l|l|r|r|l|}
\hline Model & $\mathrm{R}$ & R Square & $\begin{array}{c}\text { Adjusted } \\
\mathrm{R} \\
\text { Square }\end{array}$ & $\begin{array}{l}\text { Std. Error } \\
\text { of } \\
\text { the } \\
\text { Estimate }\end{array}$ \\
\hline 1 & $\begin{array}{l}.341(\mathrm{a} \\
)^{1}\end{array}$ & .116 & $\begin{array}{l}.08 \\
9\end{array}$ & .998 \\
\hline
\end{tabular}

a Predictors: (Constant), totalkualitas

Berdasarkan tabel diatas dijelaskan bahwa nilai dari koefisien determinan $\mathrm{R}^{2}$ adalah 0,116 atau 11,6\%. Hasil perhitungan koefisien determinan $\left(\mathrm{R}^{2}\right)$, maka selanjutnya dapat diambil kesimpulan bahwa variabel corporate image (X1), product image (X2) dan user image (X3) di resto Foresthree memiliki pengaruh sebesar $11,6 \%$ terhadap keputusan berkunjung, sedangkan sisanya $88,4 \%$ dipengaruhi oleh faktor-faktor lain di luar variabel $(\mathrm{X})$ yang tidak masuk dalam model penelitian.

Tabel 6. Hasil Uji Koefisien Determinan $\left(\mathrm{R}^{2}\right)$ Kualitas Produk

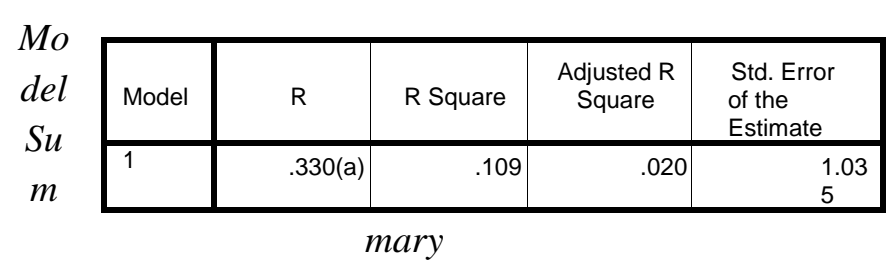

a Predictors: (Constant), totalkualitas

Sumber: Peneliti (2018)

Berdasarkan tabel di atas dijelaskan bahwa nilai dari koefisien determinan $\mathrm{R}^{2}$ adalah 0,109 atau $10,9 \%$. Hasil perhitungan koefisien determinan $\left(\mathrm{R}^{2}\right)$, maka selanjutnya dapat diambil kesimpulan bahwa variabel kualitas produk (X4) di resto Foresthree memiliki pengaruh sebesar 10,9\% terhadap keputusan berkunjung, sedangkan sisanya $89,1 \%$ dipengaruhi oleh faktor-faktor lain di luar variabel $(\mathrm{X})$ yang tidak masuk dalam model penelitian.

Maka dari itu, pengaruh brand image dan kualitas produk terhadap keputusan berkunjung ke resto Foresthree sebesar 22,5\%, sedangkan sisanya $77,5 \%$ dipengaruhi oleh faktor-faktor lain di luar variabel (X) yang tidak masuk dalam model penelitian.

\section{Analisa Hasil}

Brand image terdiri dari 3 dimensi yaitu corporate image, product image dan user 
image. Dari hasil temuan yang memiliki nilai paling tinggi pada dimensi corporate image terhadap resto Foresthree adalah brand Foresthree yang terkenal dan bisa dipercaya. Diikuti product image pada Foresthree memiliki nilai yang paling tinggi yaitu Foresthree memiliki citra produk yang bermanfaat dan citra produk yang berkualitas, dan user image pada Foresthree memiliki nilai paling tinggi yaitu brand Foresthree yang dapat meningkatkan status sosial.

Kualitas produk memiliki 9 dimensi dan telah didapat hasil dari penelitian terhadap resto Foresthree, yang memiliki nilai tertinggi yaitu tampilan makanan dan minuman, diikuti bentuk makanan, kombinasi warna dari makanan dan minuman, serta porsi makanan dan minuman, sedangkan yang memiliki nilai rendah yaitu dari segi temperatur, tekstur, aroma, tingkat kematangan dan kesesuaian dengan lidah konsumen.

Brand image pada resto Foresthree berpengaruh secara simultan terhadap keputusan berkunjung sedangkan kualitas produk pada resto Foresthree tidak berpengaruh secara simultan terhadap keputusan berkunjung.

Variabel corporate image (X1), product image $(\mathrm{X} 2)$ dan user image $(\mathrm{X} 3)$ di resto Foresthree memiliki pengaruh sebesar $11,6 \%$ terhadap keputusan berkunjung, sedangkan variabel kualitas produk (X4) di resto Foresthree memiliki pengaruh sebesar $10,9 \%$ terhadap keputusan berkunjung. Maka pengaruh brand image dan kualitas produk terhadap keputusan berkunjung ke resto Foresthree sebesar $22,5 \%$, sedangkan sisanya $77,5 \%$ dipengaruhi oleh faktorfaktor lain di luar variabel penelitian. Secara parsial brand image yaitu corporate image dan product image merupakan variabel yang berpengaruh signifikan, sedangkan yang tidak berpengaruh signifikan yaitu user image dan kualitas produk.

Berikut ini diuraikan pembahasan dari hasil hipotesis mengenai pengaruh dari keempat variabel bebas terhadap keputusan berkunjung ke resto Foresthree:

1. Pengaruh variabel corporate image (X1) terhadap keputusan berkunjung (Y)

Hasil dari pengujian regresi menunjukan nilai dari corporate image sebesar 0,009 yang berarti variabel tersebut berpengaruh terhadap keputusan berkunjung. Corporate image memiliki peran yang besar dalam mempengaruhi keputusan berkunjung. Popularitas perusahaan serta kemampuan perusahaan dalam melayani dan memenuhi kebutuhan konsumen sangat menentukan bagaimana kesan masyarakat terhadap citra perusahaan tersebut. Brand Foresthree yang sudah terkenal artinya sudah banyak konsumen yang mengetahui tentang adanya resto tersebut, dengan naiknya nama Foresthree mampu membuat resto ini bersaing dengan resto lainnya dalam bidang usaha kuliner.

Perusahaan yang memiliki citra baik produk-produknya cenderung lebih disukai dan mudah diterima dari pada perusahaan yang memiliki citra kurang baik atau citra yang netral. Sesuai dengan teori Kotler (2000) yang menyatakan bahwa salah satu prinsip yang diterapkan dalam mempengaruhi keputusan pembelian adalah citra perusahaan. Artinya bahwa dengan meningkatkan citra perusahaan, maka kepercayaan konsumen untuk mengambil keputusan pembelian akan semakin meningkat. Hal ini berarti semakin bagus citra perusahaan (corporate image) yang dimiliki Foresthree, maka akan semakin tinggi pula bagi konsumen dalam memilih keputusan berkunjung.

Dari hasil hipotesis diatas, citra perusahaan seringkali dijadikan acuan oleh 
konsumen untuk memutuskan keputusan berkunjung ketika konsumen tersebut tidak memiliki pengalaman atau pengetahuan akan suatu produk. Citra perusahaan resto Foresthree didukung dengan fasilitas seperti desain interior yang modern.

\section{Pengaruh variabel product image} (X2) terhadap keputusan berkunjung $(\mathrm{Y})$

Hasil dari pengujian regresi menunjukan nilai dari product image sebesar 0,028 yang berarti variabel tersebut berpengaruh terhadap keputusan berkunjung. Product image merupakan salah satu faktor yang berpengaruh bagi konsumen yang artinya konsumen akan senang membeli produk yang memiliki merk ternama dibandingkan memilih produk baru yang belum jelas identitasnya. Pendapat ini senada dengan teori Sciffman dan Kanuk (2008) yang menyatakan bahwa citra produk yang dirasa menyenangkan mempunyai peluang yang jauh lebih baik untuk dibeli dari pada produk yang mempunyai citra tidak menyenangkan atau netral. Konsumen akan melihat apakah citra produk yang dihasilkan resto Foresthree memberikan manfaat atau tidak, seperti untuk kesehatan. Konsumen memperhatikan dari segi higienis dan kesegaran dari makanan dan minuman yang disajikan. Hasil penelitian ini sejalan dengan teori Sutojo (2003) yang menyatakan bahwa keputusan konsumen dalam membeli barang atau jasa sangat dipengaruhi oleh citra produk, sehingga konsumen lebih memilih produk barang atau jasa yang mempunyai citra positif. Resto Foresthree meningkatkan citra produk dengan membuat brand baru untuk produknya yaitu cekekinian yang ditujukan khususnya untuk kalangan remaja. Citra dari produk yang berkualitas selalu diiringi dengan harga jual yang lebih tinggi, bahkan para konsumenpun tidak akan ragu ketika harus membayar produk dengan harga yang lebih mahal karena mereka telah percaya bahwa produk yang mereka beli memiliki kualitas yang benar-benar terjamin. Keberadaan product image menjadi alasan bagi para konsumen untuk membedakan produk resto Foresthree dengan produk milik pesaing.

3. Pengaruh variabel user image (X3) terhadap keputusan berkunjung (Y)

Hasil dari pengujian regresi menunjukan nilai dari user image sebesar 0,752 yang berarti variabel tersebut tidak berpengaruh terhadap keputusan berkunjung. User image sangat erat hubungannya dengan kepribadian konsumen. Citra pemakai meliputi gaya hidup dan status sosial. Secara umum gaya hidup dapat diartikan sebagai suatu yang dikenali dengan bagaimana orang mengahabiskan waktunya (aktivitas), apa yang penting orang pertimbangkan (minat), dan apa yang dipikirkan tentang diri sendiri dan dunia sekitar. Dalam banyak peristiwa, sering ditemukan ketika seorang konsumen memilih suatu produk atau merk berdasarkan tipe atau kepribadian mereka. Konsumen yang memiliki kepribadian dan gaya hidup yang modern cenderung lebih menyukai produk-produk bergaya modern dari pada produk-produk yang bergaya tradisional atau kuno, begitu pula sebaliknya. Namun pada hasil penelitian ini, gaya hidup dan status sosial bukanlah pengaruh yang dipertimbangkan pada konsumen untuk berkunjung ke resto Foresthree. Hal ini dianggap dengan berkunjung ke resto Foresthree tidak mencerminkan status sosial seseorang didalam masyarakat.

4. Pengaruh variabel kualitas produk (X4) terhadap keputusan berkunjung (Y) 
Hasil dari pengujian regresi menunjukan nilai dari kualitas produk sebesar 0,178 yang berarti variabel tersebut tidak berpengaruh terhadap keputusan berkunjung. Kualitas produk merupakan salah satu faktor utama, namun berdasarkan penelitian ini tidak berpengaruh terhadap keputusan berkunjung. Hal ini disebabkan karena faktor usia responden (Mahasiswa) yang berkunjung ke resto Foresthree pada penelitian ini tergolong masih muda dan cenderung lebih mengutamakan gaya hidup dibandingkan dengan kualitas. Maka hal ini tidak sesuai dengan teori menurut Sutisna (2002) yang menyatakan bahwa pemahaman konsumen tentang kualitas produk dapat dijadikan dasar terhadap proses keputusan pembelian konsumen.

\section{KESIMPULAN \& SARAN}

\section{Kesimpulan}

Berdasarkan rumusan masalah yang diajukan dalam penelitian ini dan analisis data yang telah dijelaskan pada bab sebelumnya terhadap variabelvariabel brand image menurut Aaker \& Biel (1993) dan kualitas produk menurut West, Wood dan Harger (2006) dapat disimpulkan sebagai berikut:

Brand image pada resto Foresthree dapat dilihat dari tiga indikator yaitu corporate image, product image dan user image. Secara umum tiga indikator tersebut menunjukkan nilai image yang baik, dan yang memiliki nilai paling tinggi yaitu Foresthree memiliki citra produk yang berkualitas, citra produk yang bermanfaat, citra produk yang terjamin, konsep yang sesuai dengan jati diri serta brand Foresthree yang terkenal.
Kualitas produk pada resto Foreshtree diterima baik oleh konsumen. Secara umum dari sembilan dimensi kualitas produk memiliki nilai dominan yang baik, dan urutan dari yang paling tinggi yaitu tampilan, diikuti oleh bentuk, kombinasi, porsi, rasa, tekstur, temperatur, tingkat kematangan dan aroma.

Pengaruh brand image dan kualitas produk terhadap keputusan berkunjung ke resto Foreethree menunjukkan bahwa dua variabel yaitu corporate image dan product image memiliki pengaruh signifikan, sedangkan user image dan kualitas produk tidak berpengauh signifikan. Corporate image dan product image berpengaruh positif karena dalam memilih keputusan berkunjung citra dari perusahaan sering dijadikan acuan bagi konsumen yang tidak memiliki pengalaman atau pengetahuan akan suatu produk, dan konsumen akan lebih memilih produk yang mempunyai citra positif. User image dan kualitas produk yang tidak berpengaruh signifikan hanya menjadi faktor pelengkap yang ada dalam memilih keputusan berkunjung, dan artinya komponen ini bukan berarti tidak penting.

\section{Saran}

Berdasarkan kesimpulan yang diperoleh dalam penelitian ini, maka dapat diberikan saran dan masukan yaitu:

1. Perusahaan diharapkan dapat terus meningkatkan dan mempertahankan brand image dari perusahaan itu sendiri dan juga citra dari produk- produk yang dihasilkan, karena brand image terbukti mampu menjadi acuan bagi konsumen dalam memutuskan keputusan berkunjung.

2. Perusahaan diharapkan dapat terus meningkatkan kualitas produknya dengan berbagai macam inovasi dan varian rasa agar dapat membuat konsumen merasa lebih puas dengan produk yang disajikan oleh resto 
Foresthree.

\section{DAFTAR PUSTAKA}

Aaker, David A., 1991, Managing Brand Equity : Capitalizing On The Value Of Br]and Name, New York: The Free Press.

Aaker, David A. And Biel, Alexander L., 1993, Brand Equity \& Advertising: Advertising's Role In Building Strong Brands. New Jersey: Lawrence Erlbaum Associates, Inc.

Adam \& Ebert, 2002. Analisis Persepsi Konsumen Terhadap Kualitas Produk Keramik Merek Milan di Surabaya. Jurnal: Manajemen \& Akuntansi Vol. 3

Arifianto, Muhammad Yusuf. 2010. Tayangan "Wisata Kuliner" Dan Kepuasan (studi Korelasi Antara Motivasi Menonton Tayangan "Wisata Kuliner" di Trans TV dan Kepuasan Penonton di Kalangan Mahasiswa AMPTA Yogyakarta Tahun Ajaran 2008. Surakarta: Skripsi Fakultas Ilmu Sosial Dan Ilmu Politik Program Studi Komunikasi Universitas Sebelas Maret Surakarta.

Musay, Fransisca Paramitasari. Pengaruh Brand Image Terhadap Keputusan Pembelian (Survei Pada Konsumen KFC Kawi Malang). Skripsi: Fakultas Ilmu Administrasi Universitas Brawijaya.

Heriyati, P. \& Septi. 2012. Analisis Pengaruh Brand Image dan Kualitas Produk Terhadap Keputusan Pembelian Konsumen Pada Handphone Nexian. Journal of Business Strategy and Execution.

Isnaini, Pratiwi Dini, Aslinda. 2016. Analisis Pengaruh Kualitas Pelayanan, Kualitas Produk dan Promosi terhadap
Keputusan Pemblian Kartu Simpati PT. Selular Media Infotama (Studi Kasus pada Counter di Kecamatan Bukit Intan). Jurnal: Ilmiah Manajemen Bisnis dan Terapan.

Manajemen Pemasaran, Edisi 12. Terjemahan Benyamin Molan. PT. Indeks. Jakarta.

Kurniawan, Wahab, Nailis. 2016. Pengaruh Citra Merek (Brand Image), Kualitas Pelayanan, Lokasi, dan Faktor Pribadi Terhadap Keputusan Pembelian Konsumen Pada KFC Gelael Bandar Lampung Tahun 2015. Jurnal: Ilmiah Manajemen Bisnis Dan Terapan.

Nasikan, Sasmito Andy. 2013. Faktor Internal dan Eksternal Terhadap Keputusan Pembelian Telepon Selular Merk Nokia. Jurnal: Manajemen dan Akuntansi Volume 2, Nomor 1.

Pajrin, Nurmalia. 2016. Pengaruh Citra Merek (Brand Image), Kualitas Pelayanan, Lokasi dan Faktor Pribadi Terhadap Keputusan Pembelian Konsumen Pada KFC Gelael Bandar Lampung Tahun 2015. Skripsi. Jurusan Pendidikan Ilmu Pengetahuan Sosial Universitas Lampung.

Perwira, Yudha Ridharta. 2015. Efek Perubahan Tingkat Harga, Kualitas Produk dan Kualitas Layanan Terhadap Keputusan Pembelian. Skripsi. Jakarta:

Paul, Peter J. dan Olson, Jerry C. 2000. Consumer Behavior. Perilaku Konsumen dan Strategi Pemasaran. Jilid 2. Edisi 4. Diterjemahkan oleh: Damos Sihombing. Jakarta: Erlangga.

Pratiwi, Made Suci, Suwendra, I Wayan, dan Yulianthini, Ni Nyoman. Pengaruh Citra Perusahaan, Citra Produk dan Citra Pemakai Terhadap Keputusan Pembelian Produk Foremost Pada Distro Ruby Soho di Singaraja. e-Journal: Bisma Universitas Pendidikan Ganesha 
Jurusan Manajemen (Volume 2

Tahun 2014).

Rasyidi, S. Kepala Dinas

Kebudayaan, Pariwisata dan

Ekonomi Kreatif

(Disbudparekraf). 2016.

Rianto Wahyu, Fanani, Sunarti.2014.

Pengaruh Merek dan Kebijakan

Harga Terhadap Keputusan

Pembelian (Survei pada

Pengunjung yang Memebeli dan

Mendapatkan Diskon Musiman terhadap Produk Inspired 27 di Kota Malang). Jurnal: Administrasi Bisnis.Vol.14.

Rizan, Mohamad, Handayani Kartika Lestari, dan Kresnamurti Agung. 2015. Pengaruh Citra Merek dan Kualitas Produk Terhadap Keputusan Pembelian (Studi Banding Konsumen Indomie dan Mie Sedaap). Jurnal Riset Manajemen Sains Indonesia (JRMSI). Fakultas Ekonomi Universitas Negeri Jakarta.

Saputra, Adi Wahyu. 2017. Pengaruh Citra Merek dan Kualitas Produk Terhadap Keputusan Pembelian Mobil Merek Isuzu Panther. Journal of Social And Politic, Business Administration. Jakarta: PT Indeks.

Sari, Venia Aprilia. 2017. Pengaruh Harga, Kualitas Produk dan Citra Merek Terhadap Keputusan Pembelian Teh Siap Minum dalam Kemasan Teh Botol Sosro. Journal of Social And Politic, Business Administration. Jakarta

Setiadi, N., (2003), Perilaku
Konsumen, Prenada Media Group. Jakarta: Jurnal Pengaruh Citra Perusahaan, Citra Produk, dan Citra Pemakai Terhadap Keputusan Pembelian Produk Foremost Pada Distro Ruby Soho di Singaraja.

Sugiyono, Metode Penelitian Kuantitatif Kualitatif dan $R \& D$. Bandung: Alfabeta. 2010.

Sulistyaningtyas, Mawardi, Pangestuti. 2013. Pengaruh City Branding Terhadap City Image serta Dampaknya pada Keputusan Berkunjung Wisatawan ke Kota Malang. Jurnal Administrasi Bisnis Volume 39.

Sutisna, 2002, Perilaku Konsumen dan Strategi Pemasaran, Rosda karya, Bandung.

West, Wood dan Harger. 2006. Skripsi: Analisa Pengaruh Kualitas Makanan \& Persepsi Harga Terhadap Kepuasan Konsumen D'Cost Surabaya.

Zuliarni, Annisa 2018. Pengaruh Paket Wisata Inbound Tour Panorama Destination terhadap Minat Membeli Pada Wisatawan Malaysia. Skripsi. Fakultas Pariwisata Universitas Pancasila. Jakarta. 
